\title{
Fodinibacter luteus gen. nov., sp. nov., an actinobacterium isolated from a salt mine
}

\author{
Zhi-Gang Wang, ${ }^{1}+$ Yong-Xia Wang, ${ }^{1} \dagger$ Ji-Hui Liu, ${ }^{1}$ Yi-Guang Chen, ${ }^{1,2}$ \\ Xiao-Xia Zhang, ${ }^{3}$ Meng-Liang Wen, ${ }^{1}$ Li-Hua Xu, ${ }^{1}$ Oian Peng ${ }^{1}$ \\ and Xiao-Long Cui ${ }^{1}$
}

Correspondence

Xiao-Long Cui

xlcui@ynu.edu.cn

or

xlcuiynu@yahoo.com.cn

\author{
${ }^{1}$ Yunnan Institute of Microbiology, Yunnan University, Kunming, Yunnan 650091, PR China \\ ${ }^{2}$ College of Bio-resources and Environmental Science, Jishou University, Jishou, Hunan 416000, \\ PR China \\ ${ }^{3}$ Agricultural Cultural Collection of China, Institute of Agricultural Resources and Regional Planning, \\ Chinese Academy of Agricultural Sciences, Beijing 100080, PR China
}

\begin{abstract}
A Gram-positive-staining, aerobic, catalase- and oxidase-positive, irregular short rod-shaped actinobacterium, designated strain YIM $\mathrm{COO}^{\top}$, was isolated from a salt mine in Yunnan, PR China. Phylogenetic analysis based on 16S rRNA gene sequences showed that strain YIM $\mathrm{C003}^{\top}$ was most closely related to strains of the genera Knoellia (94.2-96.0\% similarity), Oryzihumus (95.6\%), Terrabacter (94.9-95.4\%), Janibacter (94.9-95.4\%), Kribbia (95.0\%), Lapillicoccus (95.0\%) and Phycicoccus (94.2-95.0\%) of the family Intrasporangiaceae and that it formed an independent monophyletic lineage with three strains of Oryzihumus leptocrescens. The DNA $\mathrm{G}+\mathrm{C}$ content of strain $\mathrm{YIM} \mathrm{C003}{ }^{\top}$ was $72.0 \mathrm{~mol} \%$. The diagnostic cell-wall diamino acid was meso-diaminopimelic acid. The predominant menaquinone was $\mathrm{MK}-8\left(\mathrm{H}_{4}\right)$. Mycolic acids were not detected. The polar lipids were diphosphatidylglycerol, phosphatidylglycerol, phosphatidylethanolamine, phosphatidylinositol and two unknown phospholipids. The major cellular fatty acids were $C_{18: 1} \omega 9 c$ and $C_{16: 0}$. These chemotaxonomic properties, together with data from phylogenetic analysis, enabled the novel isolate to be differentiated from all other members of the family. A novel species in a new genus, Fodinibacter luteus gen. nov., sp. nov., is

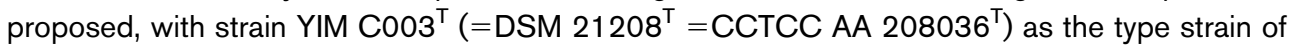
Fodinibacter luteus.
\end{abstract}

The family Intrasporangiaceae of the suborder Micrococcineae was proposed by Stackebrandt et al. (1997) on the basis of 16S rRNA gene sequence analysis. At the time of writing, the family comprised 15 recognized genera and has been divided into three groups on the basis of the diagnostic diamino acid in the cell-wall peptidoglycan: the first group has LL-diaminopimelic acid (LL-DAP) and contains six genera; the second group has L-ornithine and contains three genera; and the third group has meso-DAP and contains six genera [Janibacter (Martin et al., 1997), Tetrasphaera (Maszenan et al., 2000), Knoellia (Groth et al., 2002), Oryzihumus (Kageyama et al., 2005), Phycicoccus (Lee, 2006) and Kribbia (Jung et al., 2006)].

†These authors contributed equally to this work.

Abbreviation: DAP, diaminopimelic acid.

The GenBank/EMBL/DDBJ accession number for the 16S rRNA gene sequence of strain $\mathrm{YIM} \mathrm{COO3}^{\top}$ is EU878005.

A transmission electron micrograph of cells of strain YIM $\mathrm{COO}^{\top}$ is available as supplementary material with the online version of this paper.
The present study focuses on the taxonomic description of strain YIM $\mathrm{COO3}^{\mathrm{T}}$, which was isolated from a salt mine in Yunnan, China. On the basis of the results of a polyphasic taxonomic study, it is proposed that the strain represents a novel species in a new genus within the family Intrasporangiaceae.

Strain YIM $\mathrm{COO3}^{\mathrm{T}}$ was isolated from a sample collected from the wall of a salt mine by a standard dilution plating method on marine agar 2216 (MA, pH 7.2; Difco) plates. After incubating the agar plates at $28{ }^{\circ} \mathrm{C}$ for 21 days, strain YIM $\mathrm{COO3}^{\mathrm{T}}$ was purified as a single colony and subsequently stored as $20 \%(\mathrm{v} / \mathrm{v})$ glycerol suspensions at $-80{ }^{\circ} \mathrm{C}$. The isolate was cultured on MA, trypticase soy agar (Difco) and nutrient agar (Difco) to determine its growth rate. Growth was slow or poor on the above media and therefore a basal medium (GTM) was designed to improve it. GTM agar medium contained $10 \mathrm{~g}$ glucose, $5 \mathrm{~g}$ tryptone, $5 \mathrm{~g}$ malt extract, $3 \mathrm{~g} \mathrm{NaCl}$ and $15 \mathrm{~g}$ agar in $1 \mathrm{l}$ distilled water ( $\mathrm{pH}$ 7.2). The pure culture was then routinely maintained on GTM agar at $28{ }^{\circ} \mathrm{C}$. 
Genomic DNA extraction, PCR amplification of the $16 \mathrm{~S}$ rRNA gene and sequencing of the purified PCR products were performed as described previously (Cui et al., 2001). An almost-complete 16S rRNA gene sequence (1444 bp) of strain YIM $\mathrm{COO}^{\mathrm{T}}$ was obtained and compared with those available in GenBank using BLAST searches (Altschul et al., 1990). The 16S rRNA gene sequence of the isolate was aligned with the corresponding sequences of members of the family Intrasporangiaceae (obtained from GenBank/ EMBL/DDBJ) by using CLUSTAL_X (Thompson et al., 1997). Phylogenetic analysis was performed by using three treemaking algorithms, namely the neighbour-joining (Saitou \& Nei, 1987), maximum-parsimony (Fitch, 1971) and maximum-likelihood (Felsenstein, 1981) methods. The neighbour-joining tree was constructed from evolutionary distances calculated using Kimura's two-parameter method (Kimura, 1983). Tree topology was evaluated by bootstrap analysis based on 1000 resamplings.

The result of preliminary sequence comparisons with $16 \mathrm{~S}$ rRNA gene sequences held in GenBank showed that the isolate belonged to the family Intrasporangiaceae. Phylogenetic analysis showed that strain YIM $\mathrm{C}_{00} 3^{\mathrm{T}}$ formed a monophyletic clade with strains of Oryzihumus leptocrescens within the family Intrasporangiaceae. This relationship was also maintained in the tree based on the maximum-likelihood algorithm, but not in the tree based on the maximum-parsimony algorithm (Fig. 1). The $16 \mathrm{~S}$ rRNA gene sequence similarity between the novel strain and Oryzihumus leptocrescens $\mathrm{KV}-628^{\mathrm{T}}$ was $95.6 \%$. Strain
YIM $\mathrm{C}_{003}{ }^{\mathrm{T}}$ was also closely related to strains of other genera within the family Intrasporangiaceae from the genera Knoellia (94.2-96.0\% 16S rRNA gene sequence similarity), Terrabacter (94.9-95.4\%), Janibacter (94.995.4\%), Phycicoccus (94.2-95.0\%), Kribbia (95.0\%), Terracoccus $(95.0 \%)$, Lapillicoccus $(95.0 \%)$, Intrasporangium (94.8\%), Humihabitans (94.8\%), Tetrasphaera (94.1-94.7\%), Arsenicicoccus (94.5\%), Ornithinimicrobium (94.0\%), Ornithinicoccus (93.9\%) and Serinicoccus $(93.8 \%)$.

For phenotypic characterization, strain YIM $\mathrm{C}_{00} 3^{\mathrm{T}}$ was grown routinely on GTM agar at $28{ }^{\circ} \mathrm{C}$, unless otherwise specified. Gram staining was carried out using the standard Gram reaction combined with the $\mathrm{KOH}$ lysis test method (Gregersen, 1978). Cell morphology in 7-day-old cultures was examined by light microscopy with a model $\mathrm{BH}-2$ microscope (Olympus) and by transmission electron microscopy. The morphology, size and colour of colonies from cultures grown aerobically for 7 days were examined. Growth at different temperatures, $\mathrm{pH}$ and $\mathrm{NaCl}$ concentrations was determined on GTM agar medium. Catalase activity was determined by assessing bubble production in $3 \%(\mathrm{v} / \mathrm{v}) \mathrm{H}_{2} \mathrm{O}_{2}$ and oxidase activity was determined using a $1 \%(\mathrm{w} / \mathrm{v})$ solution of tetramethyl-p-phenylenediamine (Kovacs, 1956). Hydrolysis of hypoxanthine, starch, tyrosine, Tweens 20, 40 and 80 and xanthine was determined as described by Cowan \& Steel (1965). The ability of strain YIM $\mathrm{C}_{003}{ }^{\mathrm{T}}$ to grow on a range of sole carbon and energy sources at $0.5 \%(\mathrm{w} / \mathrm{v})$ was determined

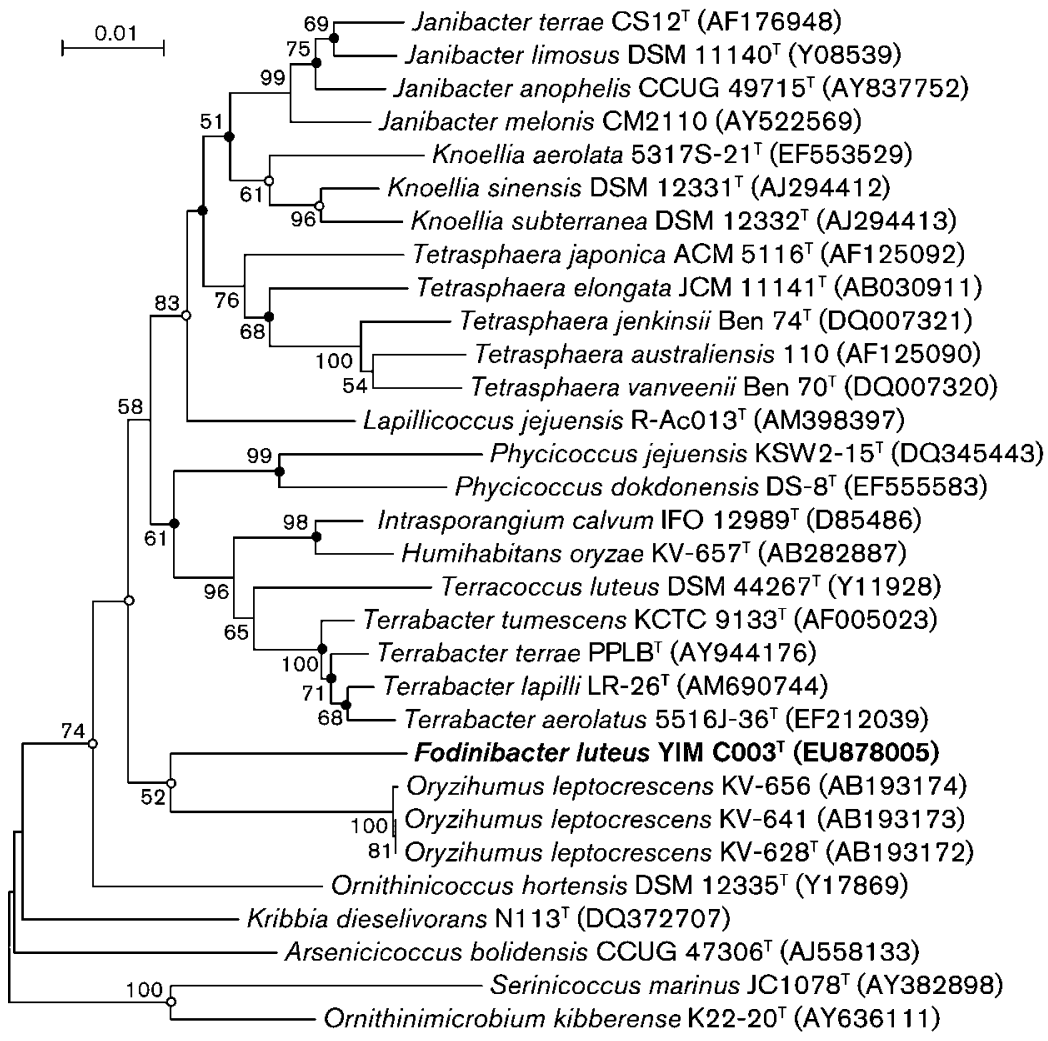

Fig. 1. Neighbour-joining phylogenetic tree showing the relationship between strain YIM $\mathrm{C}_{00} 3^{\top}$ and representatives of the family Intrasporangiaceae. Filled circles indicate that the corresponding nodes were also found in the trees generated with both maximumparsimony and maximum-likelihood algorithms; open circles indicate that the corresponding nodes were also found in the maximumlikelihood tree. Bootstrap percentages (based on 1000 replications) $>50 \%$ are shown at branching points. Bar, 0.01 substitutions per nucleotide position. 
on carbon utilization medium (Pridham \& Gottlieb, 1948). Acid production from 49 carbon sources was tested at $28{ }^{\circ} \mathrm{C}$ with the API 50CH kit combined with API 50CHB/E medium (bioMérieux). Enzyme activity tests were performed using the API ZYM kit (bioMérieux) according to the manufacturer's instructions. Other biochemical tests were carried out with API 20NE and API 20E kits (bioMérieux) according to the manufacturer's instructions.

Cells of strain YIM $\mathrm{C}_{00} 3^{\mathrm{T}}$ were aerobic, non-motile, nonendospore-forming and Gram-positive. Cells were irregular short rods at all growth stages and occurred singly or in clusters. On GTM medium, colonies were circular, smooth, convex and orange-yellow in colour with entire margins. The results of the physiological and biochemical tests are given in the species description.

The amino acid contents of the cell walls were determined according to the procedures described by Schleifer \& Kandler (1972). The amino acid composition of complete wall hydrolysates was determined by HPLC. Whole-cell sugars were identified by the method described by Becker et al. (1965). Mycolic acids were extracted and analysed according to the protocol of Minnikin et al. (1975). Polar lipids were extracted as described by Minnikin et al. (1979) and identified by two-dimensional TLC sprayed with specific reagents (Collins \& Jones, 1980). Menaquinones were extracted by using the method of Collins et al. (1977) and analysed by HPLC as described by Tamaoka et al. (1983). Biomass for quantitative fatty acid analysis of strain YIM $\mathrm{C}_{003}{ }^{\mathrm{T}}$ was prepared by scraping cells from GTM agar plates that had been incubated for 7 days at $28{ }^{\circ} \mathrm{C}$. Analysis of the whole-cell fatty acid pattern was carried out as described by Sasser (1990) using the Microbial Identification System (MIDI). The $\mathrm{G}+\mathrm{C}$ content of the genomic DNA was determined by HPLC according to Mesbah et al. (1989).

The DNA G + C content of the isolate was $72.0 \mathrm{~mol} \%$. The cell-wall peptidoglycan contained meso-DAP, alanine and glutamic acid in a molar ratio of $1.0: 1.7: 1.0$. The isolate contained peptidoglycan type A1 $\gamma$ (Schleifer \& Kandler, 1972). Whole-cell sugars were ribose and glucose. The polar lipids were phosphatidylethanolamine, phosphatidylinositol, phosphatidylglycerol, diphosphatidylglycerol and two unknown phospholipids. The menaquinone was MK$8\left(\mathrm{H}_{4}\right)(100 \%)$. Mycolic acids were not detected. The cellular fatty acids $(>1 \%$ of total fatty acids) were $\mathrm{C}_{18: 1} \omega 9 c(33.5 \%), \mathrm{C}_{16: 0}(12.6 \%)$, iso- $\mathrm{C}_{16: 0}(8.1 \%)$, $\mathrm{C}_{17: 1} \omega 8 c \quad(7.4 \%), \quad$ iso- $\mathrm{C}_{14: 0} \quad(5.3 \%), \mathrm{C}_{18: 0} \quad(5.1 \%)$, summed feature $3\left(\mathrm{C}_{16: 1} \omega 7 \mathrm{c}\right.$ and/or iso- $\mathrm{C}_{15: 0} 2-\mathrm{OH}$, $3.76 \%)$, iso- $\mathrm{C}_{15: 0}(2.9 \%), \mathrm{C}_{14: 0}(2.6 \%), \mathrm{C}_{17: 0}(2.3 \%)$, $\mathrm{C}_{18: 1} \omega 7 c(2.1 \%)$, summed feature $5\left(\mathrm{C}_{18: 2} \omega 6,9 c\right.$ and/or anteiso- $\left.\mathrm{C}_{18: 0}, 2.1 \%\right), \mathrm{C}_{15: 0}(2.1 \%)$, anteiso- $\mathrm{C}_{15: 0}(1.8 \%)$, $\mathrm{C}_{16: 1} \omega 9 c(1.3 \%)$ and anteiso- $\mathrm{C}_{17: 0}(1.2 \%)$.

The results of the phylogenetic analyses showed the phylogenetic position of strain YIM $\mathrm{C}_{003}{ }^{\mathrm{T}}$ within the family Intrasporangiaceae. In terms of $16 \mathrm{~S}$ rRNA gene sequence similarity, the closest phylogenetic neighbour was Oryzihumus leptocrescens $\mathrm{KV}-628^{\mathrm{T}}$ (95.6\% $\mathrm{similarity).}$
However, strain YIM $\mathrm{C}_{00}{ }^{\mathrm{T}}$ could be distinguished from Oryzihumus leptocrescens on the basis of the presence of phosphatidylethanolamine and phosphatidylinositol and the presence of $\mathrm{C}_{18: 1} \omega 9 c$ and $\mathrm{C}_{16: 0}$ as the major fatty acids (Table 1). Strain YIM C003 ${ }^{\mathrm{T}}$ could be readily differentiated from all other members of the family Intrasporangiaceae by differences in chemotaxonomic properties, particularly the diamino acid type in position 3 of the peptidoglycan and fatty acid profiles (Table 1). Strain YIM $\mathrm{C}_{0} 3^{\mathrm{T}}$ contained meso-DAP, which distinguished it from the genera containing LL-DAP or L-ornithine as the diagnostic diamino acid. Additionally, strain YIM $\mathrm{C}_{003}{ }^{\mathrm{T}}$ contained $\mathrm{C}_{18: 0} \omega 9 \mathrm{c}$ and $\mathrm{C}_{16: 0}$ as the major fatty acids, which distinguished it from recognized genera with meso-DAP as the diagnostic acid of the cell-well peptidoglycan in the family Intrasporangiaceae. Although there may be differences in the proportions of some fatty acids (probably due to differences in cultivation conditions and extraction procedures) (Table 1 ), the fatty acid $\mathrm{C}_{16: 0}$ was the major fatty acid in strain YIM $\mathrm{C003}^{\mathrm{T}}$. This fatty acid is absent (or present as a minor component) in all other genera of the family Intrasporangiaceae, except members of the genus Kribbia. However, strain YIM $\mathrm{C}_{00} 3^{\mathrm{T}}$ could be differentiated from members of the genus Kribbia based on the absence of 10-methyl $\mathrm{C}_{18: 0}(17.9-18.5 \%$ in Kribbia dieselivorans; Jung et al., 2006). Furthermore, the fatty acid iso- $\mathrm{C}_{15: 0}$ was a minor component in strain YIM $\mathrm{C}_{003}{ }^{\mathrm{T}}$, whereas it is a major component in most recognized genera of the family Intrasporangiaceae.

On the basis of the phylogenetic data and differential chemotaxonomic properties reported here, it is suggested that strain YIM $\mathrm{CO} 3^{\mathrm{T}}$ represents a novel species in a new genus within the family Intrasporangiaceae, for which the name Fodinibacter luteus gen. nov., sp. nov. is proposed.

\section{Description of Fodinibacter gen. nov.}

Fodinibacter (Fo.di.ni.bac'ter. L. fem. n. fodina mine; N.L. masc. n. bacter rod; N.L. masc. n. Fodinibacter rod bacterium isolated from a mine).

Cells stain Gram-positive. Oxidase- and catalase-positive. Cells are non-endospore-forming, non-motile and irregular short rods. Cells occur singly or in clusters. The peptidoglycan is of the Al $\gamma$ type, containing meso-DAP, glutamic acid and alanine. Mycolic acids are not present. The predominant menaquinone is MK- $8\left(\mathrm{H}_{4}\right)$. The polar lipid profile contains phosphatidylethanolamine, phosphatidylinositol, phosphatidylglycerol, diphosphatidylglycerol and two unknown phospholipids. The predominant cellular fatty acids are $\mathrm{C}_{18: 1} \omega 9 \mathrm{c}$ and $\mathrm{C}_{16: 0}$. Phylogenetically, the genus belongs to the family Intrasporangiaceae, suborder Micrococcineae. The type species is Fodinibacter luteus.

\section{Description of Fodinibacter luteus sp. nov.}

Fodinibacter luteus (lu'te.us. L. masc. adj. luteus orangeyellow, referring to the colony colour). 
Table 1. Differential characteristics of strain YIM $\mathrm{COO}^{\top}$ and genera of the family Intrasporangiaceae

Taxa: 1, Fodinibacter luteus YIM C003 ${ }^{\mathrm{T}}$; 2, Knoellia (data from Groth et al., 2002; Weon et al., 2007); 3, Oryzihumus (unless indicated, data from Kageyama et al., 2005); 4, Janibacter (Martin et al. 1997; Imamura et al., 2000; Yoon et al., 2000, 2004; Kämpfer et al., 2006); 5, Kribbia (Jung et al., 2006); 6, Tetrasphaera (Maszenan et al., 2000; Hanada et al., 2002); 7, Phycicoccus (Lee, 2006; Yoon et al., 2008); 8, Arsenicicoccus (Collins et al., 2004); 9, Ornithinimicrobium (Groth et al., 2001); 10, Serinicoccus (Yi et al., 2004); 11, Ornithinicoccus (Groth et al., 1999); 12, Intrasporangium (Kalakoutskii et al., 1967; Schumann et al., 1997; Groth et al., 2001); 13, Terracoccus (Prauser et al., 1997); 14, Terrabacter (Collins et al., 1989; Montero-Barrientos et al., 2005; Lee et al., 2008); 15, Humihabitans (Kageyama et al., 2007); 16, Lapillicoccus (Lee \& Lee, 2007). L-Orn, L-Ornithine; i-, iso-branched; ai-, anteiso-branched; Me, methyl; ND, no data available.

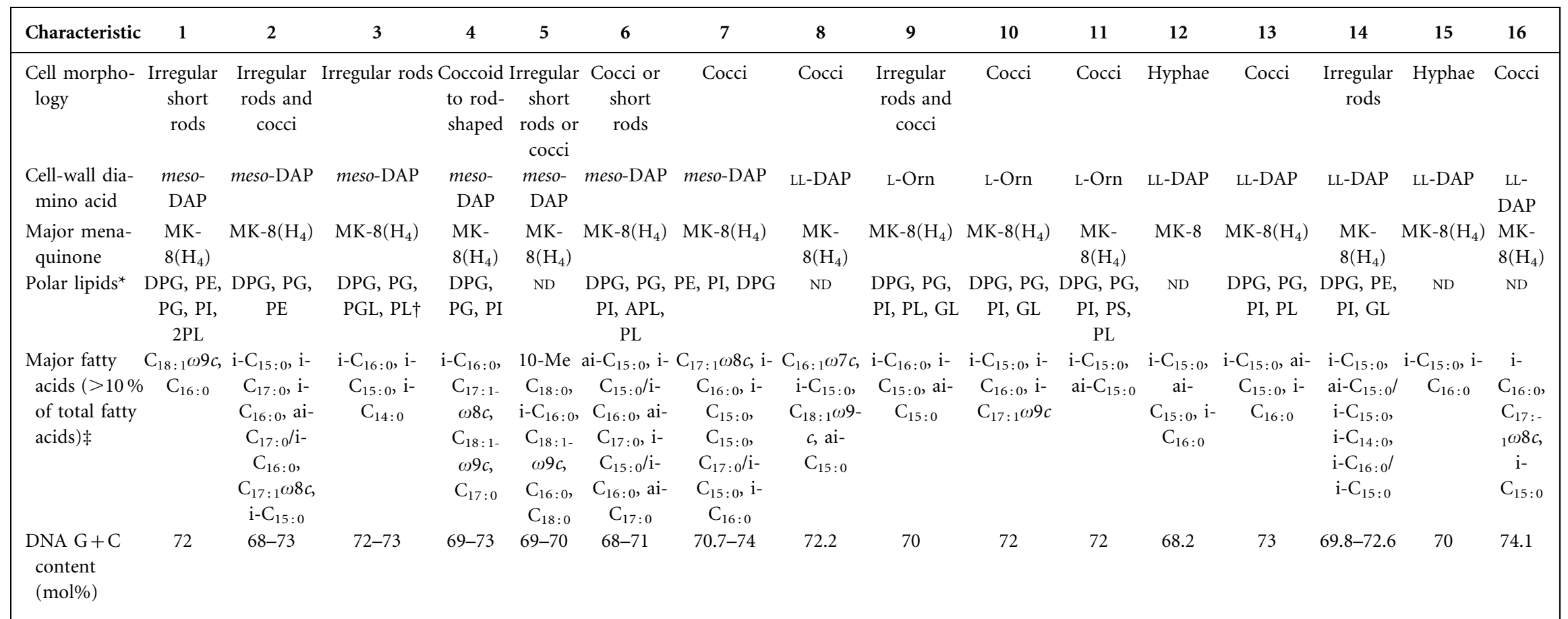

*APL, Unknown aminophospholipid; DPG, diphosphatidylglycerol; PE, phosphatidylethanolamine; PG, phosphatidylglycerol; PI, phosphatidylinositol; PL, unknown phospholipid; PGL, unknown phosphoglycolipid; GL, unknown glycolipid.

$\dagger$ Data from this study.

¥Different groups of fatty acids, each separated by a solidus, may be present, depending on the species. 
In addition to the morphological, chemotaxonomic and general characteristics described for the genus, cells are 0.3$0.6 \times 0.7-2.2 \mu \mathrm{m}$. Growth occurs at $15-37{ }^{\circ} \mathrm{C}$ with an optimum at $28{ }^{\circ} \mathrm{C}$. Optimal growth at $\mathrm{pH} 6.5-7.5 . \mathrm{NaCl}$ tolerance on GTM agar medium is $2.5 \%(\mathrm{w} / \mathrm{v})$. Only very weak growth is observed on GTM agar without $\mathrm{NaCl}$. Anaerobic growth does not occur on GTM using the GasPak anaerobic system (BBL). Acetate, D-galactose, Dglucose, maltose, melibiose and pyruvate are utilized as sole carbon and energy sources, sucrose and trehalose are utilized weakly and L-arabinose, benzoate, cellobiose, citrate, formate, D-fructose, L-glutamate, L-malate, Dmannose, salicin, succinate and D-xylose are not utilized. Acid is produced from D-glucose. Acid is not produced from L-arabinose, cellobiose, D-fructose, D-galactose, myoinositol, lactose, maltose, D-mannitol, melezitose, raffinose, L-rhamnose, D-ribose, sucrose, D-sorbitol or trehalose. Aesculin, gelatin and Tweens 20, 40 and 80 are hydrolysed, but hypoxanthine, starch, tyrosine and xanthine are not. With the API 20E kit (bioMérieux), arginine dihydrolase and $\beta$-galactosidase are present, lysine decarboxylase, ornithine decarboxylase and urease are absent and $\mathrm{H}_{2} \mathrm{~S}$ and indole are not produced. Nitrate is reduced to nitrite (API 20NE). In assays with the API ZYM system (bioMérieux), tests positive for alkaline phosphatase, esterase C4, esterase lipase C8, lipase C14, leucine arylamidase, acid phosphatase, cystine arylamidase, valine arylamidase, $\alpha$-chymotrypsin, trypsin and $\beta$-galactosidase, but negative for $N$-acetyl- $\beta$-glucosaminidase, $\alpha$-glucosidase, $\beta$-glucosidase, $\beta$-glucuronidase, fucosidase, naphtholAS-BI-phosphohydrolase, $\alpha$-mannosidase and $\alpha$-galactosidase.

The type strain is YIM $003^{\mathrm{T}}\left(=\mathrm{DSM} 21208^{\mathrm{T}}=\right.$ CCTCC AA $208036^{\mathrm{T}}$ ), isolated from a sample collected from the wall of a salt mine in Yunnan. The DNA G $+\mathrm{C}$ content of the type strain is $72.0 \mathrm{~mol} \%$.

\section{Acknowledgements}

This work was supported by grants from the National Natural Science Foundation of China (30860013, 30460004, 30660004, 30760006), the Ministry of Science and Technology of China (863 Program, no. 2007AA021306; 2006BAE01A01-9), the Ministry of Environmental Protection of China (National Key Sciences and Technology Program for Water Solutions, 2008ZX07102-004), the Yunnan Provincial Sciences and Technology Department (2005PY01-1, 2006C0006M) and Yunnan University (2008BY005). We are grateful to Ms Ya-Ling Yang for her help during sampling and to Professor Dr Hans G. Trüper for recommending the correct etymology for the genus and species names.

\section{References}

Altschul, S. F., Gish, W., Miller, W., Myers, E. W. \& Lipman, D. J. (1990). Basic local alignment search tool. J Mol Biol 215, 403-410.

Becker, B., Lechevalier, M. P. \& Lechevalier, H. A. (1965). Chemical composition of cell-wall preparation from strains of various formgenera of aerobic actinomycetes. Appl Microbiol 13, 236-243.
Collins, M. D. \& Jones, D. (1980). Lipids in the classification and identification of coryneform bacteria containing peptidoglycans based on 2,4-diaminobutyric acid. J Appl Bacteriol 48, 459-470.

Collins, M. D., Pirouz, T., Goodfellow, M. \& Minnikin, D. E. (1977). Distribution of menaquinones in actinomycetes and corynebacteria. J Gen Microbiol 100, 221-230.

Collins, M. D., Dorsch, M. \& Stackebrandt, E. (1989). Transfer of Pimelobacter tumescens to Terrabacter gen. nov. as Terrabacter tumescens comb. nov. and of Pimelobacter jensenii to Nocardioides as Nocardioides jensenii comb. nov. Int J Syst Bacteriol 39, 1-6.

Collins, M. D., Routh, J., Saraswathy, A., Lawson, P. A., Schumann, P., Welinder-Olsson, C. \& Falsen, E. (2004). Arsenicicoccus bolidensis gen. nov., sp. nov., a novel actinomycete isolated from contaminated lake sediment. Int J Syst Evol Microbiol 54, 605-608.

Cowan, S. T. \& Steel, K. J. (1965). Manual for the Identification of Medical Bacteria. London: Cambridge University Press.

Cui, X. L., Mao, P. H., Zeng, M., Li, W. J., Zhang, L. P., Xu, L. H. \& Jiang, C. L. (2001). Streptimonospora salina gen. nov., sp. nov., a new member of the family Nocardiopsaceae. Int J Syst Evol Microbiol 51, 357-363.

Felsenstein, J. (1981). Evolutionary trees from DNA sequences: a maximum likelihood approach. J Mol Evol 17, 368-376.

Fitch, W. M. (1971). Toward defining the course of evolution: minimum change for a specific tree topology. Syst Zool 20, 406-416.

Gregersen, T. (1978). Rapid method for distinction of Gram-negative from Gram-positive bacteria. Eur J Appl Microbiol Biotechnol 5, 123127.

Groth, I., Schumann, P., Martin, K., Schuetze, B., Augsten, K., Kramer, I. \& Stackebrandt, E. (1999). Ornithinicoccus hortensis gen. nov., sp. nov., a soil actinomycete which contains L-ornithine. Int $J$ Syst Bacteriol 49, 1717-1724.

Groth, I., Schumann, P., Weiss, N., Schuetze, B., Augsten, K. \& Stackebrandt, E. (2001). Ornithinimicrobium humiphilum gen. nov., sp. nov., a novel soil actinomycete with L-ornithine in the peptidoglycan. Int J Syst Evol Microbiol 51, 81-87.

Groth, I., Schumann, P., Schütze, B., Augsten, K. \& Stackebrandt, E. (2002). Knoellia sinensis gen. nov., sp. nov. and Knoellia subterranean sp. nov., two novel actinobacteria isolated from a cave. Int J Syst Evol Microbiol 52, 77-84.

Hanada, S., Liu, W.-T., Shintani, T., Kamagata, Y. \& Nakamura, K. (2002). Tetrasphaera elongata sp. nov., a polyphosphate-accumulating bacterium isolated from activated sludge. Int J Syst Evol Microbiol 52, 883-887.

Imamura, Y., Ikeda, M., Yoshida, S. \& Kuraishi, H. (2000). Janibacter brevis sp. nov., a new trichloroethylene-degrading bacterium isolated from polluted environments. Int J Syst Evol Microbiol 50, 1899-1903.

Jung, S. Y., Kim, H. S., Song, J. J., Lee, S. G., Oh, T. K. \& Yoon, J. H. (2006). Kribbia dieselivorans gen. nov., sp. nov., a novel member of the family Intrasporangiaceae. Int J Syst Evol Microbiol 56, 2427-2432.

Kageyama, A., Takahashi, Y., Seki, T., Tomoda, H. \& Ōmura, S. (2005). Oryzihumus leptocrescens gen. nov., sp. nov. Int J Syst Evol Microbiol 55, 2555-2559.

Kageyama, A., Takahashi, Y. \& Ōmura, S. (2007). Humihabitans oryzae gen. nov., sp. nov. Int J Syst Evol Microbiol 57, 2163-2166.

Kalakoutskii, L. V., Kirillova, I. P. \& Krasil'nikov, N. A. (1967). A new genus of the Actinomycetales - Intrasporangium gen. nov. J Gen Microbiol 48, 79-85.

Kämpfer, P., Terenius, O., Lindh, J. M. \& Faye, I. (2006). Janibacter anophelis sp. nov., isolated from the midgut of Anopheles arabiensis. Int J Syst Evol Microbiol 56, 389-392. 
Kimura, M. (1983). The Neutral Theory of Molecular Evolution. Cambridge: Cambridge University Press.

Kovacs, N. (1956). Identification of Pseudomonas pyocyanea by oxidase reaction. Nature 178, 703 .

Lee, S. D. (2006). Phycicoccus jejuensis gen. nov., sp. nov., an actinomycete isolated from seaweed. Int J Syst Evol Microbiol 56, 2369-2373.

Lee, S. D. \& Lee, D. W. (2007). Lapillicoccus jejuensis gen. nov., sp. nov., a novel actinobacterium of the family Intrasporangiaceae, isolated from stone. Int J Syst Evol Microbiol 57, 2794-2798.

Lee, J. E., Seo, J. P., Lee, D. W., Ko, Y. H. \& Lee, S. D. (2008). Terrabacter lapilli sp. nov., an actinomycete isolated from stone. Int $J$ Syst Evol Microbiol 58, 1084-1088.

Martin, K., Schumann, P., Rainey, F. A., Schuetze, B. \& Groth, I. (1997). Janibacter limosus gen. nov., sp. nov., a new actinomycete with meso-diaminopimelic acid in the cell wall. Int J Syst Bacteriol 47, 529534 .

Maszenan, A. M., Seviour, R. J., Patel, B. K. C., Schumann, P., Burghardt, J., Tokiwa, Y. \& Stratton, H. M. (2000). Three isolates of novel polyphosphate-accumulating Gram-positive cocci, obtained from activated sludge, belong to a new genus, Tetrasphaera gen. nov., and description of two new species, Tetrasphaera japonica sp. nov. and Tetrasphaera australiensis sp. nov. Int J Syst Evol Microbiol 50, 593-603.

Mesbah, M., Premachandran, U. \& Whitman, W. B. (1989). Precise measurement of the $\mathrm{G}+\mathrm{C}$ content of deoxyribonucleic acid by highperformance liquid chromatography. Int J Syst Bacteriol 39, 159-167.

Minnikin, D. E., Alshamaony, L. \& Goodfellow, M. (1975). Differentiation of Mycobacterium, Nocardia, and related taxa by thin-layer chromatographic analysis of whole-organism methanolysates. J Gen Microbiol 88, 200-204.

Minnikin, D. E., Collins, M. D. \& Goodfellow, M. (1979). Fatty acid and polar lipid composition in the classification of Cellulomonas, Oerskovia and related taxa. J Appl Bacteriol 47, 87-95.

Montero-Barrientos, M., Rivas, R., Velázquez, E., Monte, E. \& Roig, M. G. (2005). Terrabacter terrae sp. nov., a novel actinomycete isolated from soil in Spain. Int J Syst Evol Microbiol 55, 2491-2495.

Prauser, H., Schumann, P., Rainey, F. A., Kroppenstedt, R. M. \& Stackebrandt, E. (1997). Terracoccus luteus gen. nov., sp. nov., an LLdiaminopimelic acid-containing coccoid actinomycete from soil. Int $\mathrm{J}$ Syst Bacteriol 47, 1218-1224.
Pridham, T. G. \& Gottlieb, D. (1948). The utilization of carbon compounds by some actinomycetales as an aid for species determination. J Bacteriol 56, 107-114.

Saitou, N. \& Nei, M. (1987). The neighbor-joining method: a new method for reconstructing phylogenetic trees. Mol Biol Evol 4, 406425.

Sasser, M. (1990). Identification of bacteria by gas chromatography of cellular fatty acids. USFCC Newsl 20, 16.

Schleifer, K. H. \& Kandler, O. (1972). Peptidoglycan types of bacterial cell walls and their taxonomic implications. Bacteriol Rev 36, 407-477.

Schumann, P., Prauser, H., Rainey, F. A., Stackebrandt, E. \& Hirsch, P. (1997). Friedmanniella antarctica gen. nov., sp. nov., an LLdiaminopimelic acid-containing actinomycete from Antarctic sandstone. Int J Syst Bacteriol 47, 278-283.

Stackebrandt, E., Rainey, F. A. \& Ward-Rainey, N. L. (1997). Proposal for a new hierarchic classification system, Actinobacteria classis nov. Int J Syst Bacteriol 47, 479-491.

Tamaoka, J., Katayama-Fujimura, Y. \& Kuraishi, H. (1983). Analysis of bacterial menaquinone mixtures by high performance liquid chromatography. J Appl Bacteriol 54, 31-36.

Thompson, J. D., Gibson, T. J., Plewniak, F., Jeanmougin, F. \& Higgins, D. G. (1997). The CLUSTAL_X windows interface: flexible strategies for multiple sequence alignment aided by quality analysis tools. Nucleic Acids Res 25, 4876-4882.

Weon, H. Y., Kim, B. Y., Schumann, P., Kroppenstedt, R. M., Noh, H. J., Park, C. W. \& Kwon, S. W. (2007). Knoellia aerolata sp. nov., isolated from an air sample in Korea. Int J Syst Evol Microbiol 57, 2861-2864.

Yi, H., Schumann, P., Sohn, K. \& Chun, J. (2004). Serinicoccus marinus gen. nov., sp. nov., a novel actinomycete with L-ornithine and L-serine in the peptidoglycan. Int J Syst Evol Microbiol 54, 1585-1589.

Yoon, J. H., Lee, K. C., Kang, S. S., Kho, Y. H., Kang, K. H. \& Park, Y. H. (2000). Janibacter terrae sp. nov., a bacterium isolated from soil around a wastewater treatment plant. Int J Syst Evol Microbiol 50, 1821-1827.

Yoon, J. H., Lee, H. B., Yeo, S. H. \& Choi, J. E. (2004). Janibacter melonis sp. nov., isolated from abnormally spoiled oriental melon in Korea. Int J Syst Evol Microbiol 54, 1975-1980.

Yoon, J. H., Lee, S. Y., Kang, S. J. \& Oh, T. K. (2008). Phycicoccus dokdonensis sp. nov., isolated from soil. Int J Syst Evol Microbiol 58, 597-600. 